\title{
Simulating the mid-Pliocene Warm Period with the CCSM4 model
}

\author{
N. A. Rosenbloom, B. L. Otto-Bliesner, E. C. Brady, and P. J. Lawrence \\ National Center for Atmospheric Research, 1850 Table Mesa Drive, Boulder, Colorado, CO 80305, USA \\ Correspondence to: N. A. Rosenbloom (nanr@ucar.edu)
}

Received: 27 November 2012 - Published in Geosci. Model Dev. Discuss.: 13 December 2012

Revised: 14 March 2013 - Accepted: 22 March 2013 - Published: 26 April 2013

\begin{abstract}
This paper describes the experimental design and model results from a $500 \mathrm{yr}$ fully coupled Community Climate System, version 4, simulation of the midPliocene Warm Period (mPWP) (ca. 3.3-3.0 Ma). We simulate the mPWP using the "alternate" protocol prescribed by the Pliocene Model Intercomparison Project (PlioMIP) for the AOGCM simulation (Experiment 2). Results from the CCSM4 mPWP simulation show a $1.9^{\circ} \mathrm{C}$ increase in global mean annual temperature compared to the 1850 preindustrial control, with a polar amplification of $\sim 3$ times the global warming. Global precipitation increases slightly by $0.09 \mathrm{~mm} \mathrm{day}^{-1}$ and the monsoon rainfall is enhanced, particularly in the Northern Hemisphere (NH). Areal sea ice extent decreases in both hemispheres but persists through the summers. The model simulates a relaxation of the zonal sea surface temperature (SST) gradient in the tropical Pacific, with the El Niño-Southern Oscillation (Niño3.4) $20 \%$ weaker than the preindustrial and exhibiting extended periods of quiescence of up to $150 \mathrm{yr}$. The maximum Atlantic meridional overturning circulation and northward Atlantic oceanic heat transport are indistinguishable from the control. As compared to PRISM3, CCSM4 overestimates Southern Hemisphere (SH) sea surface temperatures, but underestimates $\mathrm{NH}$ warming, particularly in the North Atlantic, suggesting that an increase in northward ocean heat transport would bring CCSM4 SSTs into better alignment with proxy data.
\end{abstract}

\section{Introduction}

This paper describes the experimental design and model results from a $500 \mathrm{yr}$ fully coupled Community Climate System, version 4, simulation of the mid-Pliocene Warm Period (mPWP) using the Community Climate System Model, version 4 (CCSM4). The mPWP (ca. 3.3-3.0 Ma) is the last period of sustained warmth before the onset of Pleistocene glaciation. Temperature reconstructions from proxies point to a $2-3{ }^{\circ} \mathrm{C}$ increase in mean global surface temperature over present day (Dowsett, 2007), with high-latitude temperatures as much as $15-20^{\circ} \mathrm{C}$ warmer than modern (Ballantyne et al., 2010). The mPWP is also the most recent prolonged period in Earth history when $\mathrm{CO}_{2}$ concentrations were similar to present day. It is, therefore, of particular interest because unlike other warm periods in Earth history, we have relatively abundant proxy data that provide good estimates of both land and ocean temperatures. However, the enigma of the MPWP is that although continental configurations and ocean bathymetry were close to modern and estimated $\mathrm{CO}_{2}$ concentrations (405 ppmv; Pagani, 2010), and were only incrementally higher than present-day values (391 ppm; October 2012, Mauna Loa; http://www.esrl.noaa.gov/gmd/ ccgg/trends/), proxy evidence reveals a much lower pole-toequator temperature gradient and a more equable seasonal climate overall (Ballantyne et al., 2010). By simulating the $\mathrm{mPWP}$ and comparing it to proxy records that show evidence of a strong climate response to $\mathrm{CO}_{2}$ forcing, we look through an imperfect lens onto a warm world in hope that it may help us to understand the response of future climate to increasingly higher concentrations of atmospheric greenhouse gases. In the process we test the ability of the CCSM4 model to sustain an alternate state of the Earth climate system that looks very different from that of the present day.

\section{Model description}

To simulate the mPWP we use CCSM4 (Gent et al., 2011), which has active atmosphere, land, ocean, and sea ice component models that are linked through a coupler that exchanges state information and fluxes between the components. 


\subsection{Atmosphere}

The atmosphere component model in CCSM4 is the Community Atmosphere Model, version 4 (CAM4) (Neale et al., 2013). The default version of the CAM4 model changed from the spectral core used in CCSM3/CAM3 to the LinRood finite volume (FV) core (Lin, 2004) (CAM4-FV). The CAM4-FV model has improved spatial and temporal aspects of ENSO over the CAM3 model (Richter and Rasch, 2008; Neale et al., 2008; Deser et al., 2012). Changes to cloud fraction calculations improve Arctic cloud formation and lead to a more realistic polar response. However, comparisons with satellite observations indicate that CAM4 continues to have long-standing cloud biases (Kay et al., 2012a), which tend to suppress surface warming and sea ice loss in the Arctic (Kay et al., 2012b). We use a $\sim 1^{\circ}$ horizontal grid for CAM4, with $192 \times 288$ latitude/longitude grid cells and a uniform resolution of $0.9^{\circ}$ in latitude $\times 1.25^{\circ}$ in longitude. CAM4 uses 26 layers in the vertical, which are distributed similarly to CAM3.

\subsection{Land}

The CCSM4 uses the Community Land Model, version 4 (CLM4, Lawrence et al., 2012). The CLM4 model differs from CLM3, used in CCSM3, by the addition of a carbon-nitrogen $(\mathrm{CN})$ biogeochemical model, revised hydrology, landcover and land use algorithms, and soil and snow submodels. These modifications lead to improvements in soil water storage, evapotranspiration, surface albedo, and permafrost in fully coupled CCSM4 simulations. The global land precipitation bias is larger in CCSM4 relative to CCSM3, but the global land air temperature bias is reduced and the annual cycle is improved, especially in high latitudes. CCSM4/CLM4 relies on an embedded river transport model (RTM, Branstetter and Famiglietti, 1999) to carry gridcell runoff to the ocean along a model approximation of real-world river networks. The land (CLM4) and atmosphere (CAM4) component models share the same $0.9^{\circ}$ latitude $\times 1.25^{\circ}$ longitude horizontal grid; RTM resolution is $0.5^{\circ}$ latitude/longitude grid.

\subsection{Ocean}

The CCSM4 ocean component model (POP2) is based on the "Parallel Ocean Program", version 2 (Smith et al., 2010). We use the standard CCSM4 displaced-pole ocean grid with poles in Greenland and Antarctica. The ocean grid has $320 \times$ 384 points with nominally $1^{\circ}$ resolution except near the equator, where the latitudinal resolution becomes finer, as described in Danabasoglu et al. (2006). The number of vertical levels in the ocean increased from 40 to 60 in CCSM4, allowing for twenty $10 \mathrm{~m}$ levels in the upper ocean. A new overflow parameterization was added to represent density-driven flows in the Denmark Strait, Faroe Bank Channel, Ross Sea and Weddell Sea (Danabasoglu et al., 2010; Briegleb et al.,
2010). Overall, the CCSM4 ocean model shows clear improvement in reducing sea surface temperature (SST) and sea surface salinity (SSS) biases relative to the CCSM3 (Gent et al., 2011; Danabasoglu et al., 2012), notably in the North Atlantic, where slight changes in the Gulf Stream and North Atlantic currents reduce but do not eliminate the negative SST and fresh SSS biases along the North Atlantic Current path, while increasing the warm SST and saline biases off the North American coast. Despite these improvements, the ocean model continues to lose heat content for the duration of the preindustrial control simulation (Danabasoglu et al., 2012). Maximum North Atlantic overturning ( $>24 \mathrm{~Sv}$ ) is stronger in CCSM4 than it was in CCSM3 ( $>20 \mathrm{~Sv}$ ) (Gent et al., 2011).

\subsection{Sea ice}

The CCSM4 sea ice component model (CICE4) is based on version 4 of the Los Alamos National Laboratory "Community Ice Code" sea ice model (Hunke and Lipscomb, 2008). The sea ice component models in CCSM3 and CCSM4 are generally similar. However, CICE4 incorporates a sophisticated new shortwave radiative transfer scheme that significantly improves the representation of sea ice radiative transfer by using inherent optical properties to define scattering and absorption characteristics of snow and ice. The new model also explicitly accounts for melt ponds and the radiative impacts of aerosols on sea ice. The radiative impact of melt ponds and aerosols on preindustrial Arctic sea ice is $1.1 \mathrm{~W} \mathrm{~m}^{-2}$ annually (Holland et al., 2012), whereas they have negligible impact on Antarctic sea ice. In general, Arctic sea ice thickness, areal extent, and spatial pattern compare well to observations in the CCSM4 twentieth-century simulations (Jahn et al., 2012). CCSM4 sea ice extents in the Labrador Sea and adjacent North Atlantic have been reduced relative to CCSM3, and the southern Labrador Sea is now ice free. Antarctic sea ice distribution is similar to CCSM3, but still too extensive relative to observations (Landrum et al., 2012). CICE4 uses the same horizontal grid as the ocean component (POP2).

\section{Experimental design of mPWP simulation}

This simulation is one of a coordinated set of model experiments, collectively known as the Pliocene Model Intercomparison Project (PlioMIP). PlioMIP is part of the broader scale Paleoclimate Modeling Intercomparison Project (PMIP3; http://pmip3.lsce.ipsl.fr/). The first phase of PlioMIP includes two modeling experiments (Haywood et al., 2010, 2011). The first experiment compares atmosphereonly (AGCM) climate models; the second contrasts fully coupled ocean-atmosphere (AOGCM) climate models. In this paper we outline the implementation we used to complete the second, fully coupled experiment (Haywood et al., 2011) with the CCSM4 climate model. NCAR did not undertake the atmosphere-only (AGCM) experiment. 
The PlioMIP models use forcing and boundary conditions specified by the USGS Pliocene Research Interpretation and Synoptic Mapping project, version 3 (PRISM3; http: //geology.er.usgs.gov/eespteam/prism/). The PlioMIP protocol for the AOGCM experiment outlines two model configurations: "preferred" and "alternate", and PRISM3 provides separate boundary condition data packages to accommodate each configuration. The "preferred" data package includes a land/sea mask that is faithful to what is known about the mPWP, including removal of the West Antarctic Ice Sheet (WAIS). The "alternate" configuration allows modeling groups to modify their modern land/sea mask to the extent practical for their model, specifying, for example, West Antarctica as ice-free land. We use the "alternate" configuration for the CCSM4 PlioMIP simulation. The forcings and boundary conditions for the MPWP simulation are discussed below and summarized in Table 1 .

\subsection{CCSM4 preindustrial control simulation}

We initialize the mPWP experiment from a long CCSM4 1850 preindustrial (PI) control simulation that was run to approximate equilibrium in accordance with CMIP5 (Coupled Model Intercomparison Project Phase 5) protocols. The PI control simulation uses CLM4 vegetation based on MODIS data (Lawrence and Chase, 2007), topography based on the USGS GTOPO30 digital elevation model, lakes and wetlands derived from Cogley's (1991) $1^{\circ} \times 1^{\circ}$ dataset for perennial freshwater lakes and swamps/marshes, and glaciers based on the IGBP DISCover dataset (Loveland et al., 2000). Initial conditions for the ocean are described in Gent et al. (2011). The PI control simulated 1300 model yr with constant $\mathrm{CO}_{2}$ (284.7 ppm), $\mathrm{N}_{2} \mathrm{O}$ (275.68 ppb), and $\mathrm{CH}_{4}$ (791.6 ppb), fixed incoming solar radiation at the top of the atmosphere $\left(1360.9 \mathrm{~W} \mathrm{~m}^{-2}\right)$ and prescribed aerosols (black and organic carbon, sulfate, dust and sea salt). Aerosol concentrations are specified from a historical CCSM chemistry run with prescribed emissions (Lamarque et al., 2010), plus a low-level background component to account for volcanic activity (Gent et al., 2011).

\subsection{Land/sea mask}

In the mPWP the continents were very close to their current locations, allowing us to use the modern CCSM4 land/sea mask for most of the globe. However, we modify the modern land/sea mask to remove Hudson Bay, a modern epicontinental sea formed by excavation and deformation of the Canadian Shield under the weight of Pleistocene ice (Fig. 1), requiring the creation of new coupler mapping files. As for our preindustrial control simulation, the Central American Seaway (Panama Gateway) is closed; modern ocean gateways, including the Bering Strait, Drake Passage, Tasman Gateway, Gibralter Strait, and the Indonesian Gateway, remain open.

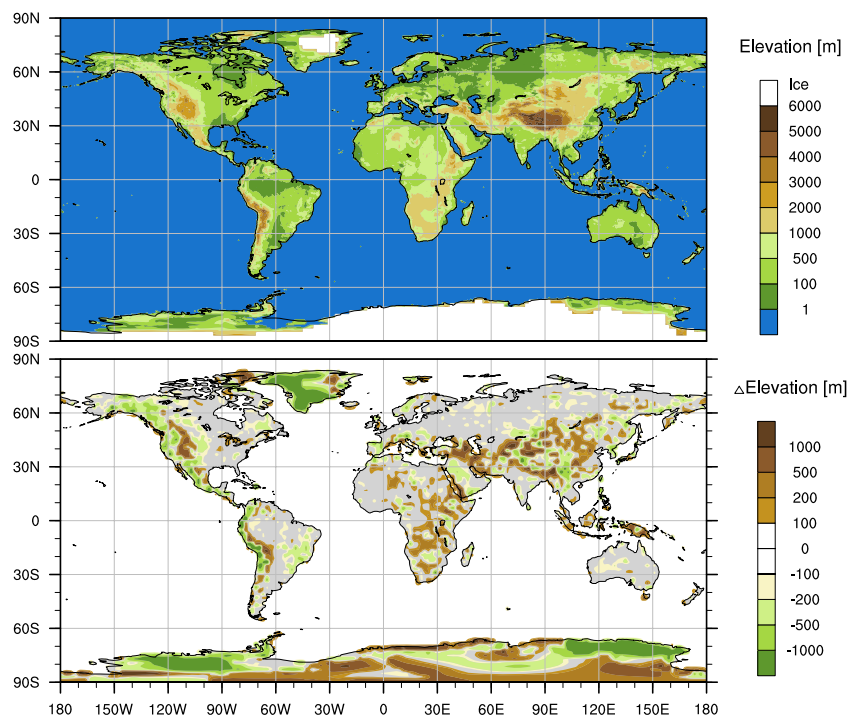

Fig. 1. CCSM4 implementation of PRISM3 land ice distribution and elevation map (top) and elevation anomaly (bottom).

\subsection{Topography and river routing}

We create the mPWP topography by adding the PRISM3 topographic anomaly (mPWP minus modern) (Sohl et al., 2009; Amante and Eakins, 2008) to the CCSM4 modern topography. Implicit in the PRISM3 topographic anomaly is a $25 \mathrm{~m}$ increase in mean sea level, which we implement in CCSM4 without changing global coastlines. The largest changes in elevation are over Greenland and West Antarctica, where PRISM3 reduces the volume of continental ice sheets to reflect the $25 \mathrm{~m}$ sea level change. Local elevation adjustments also affect the North American Rocky Mountains, the Middle East, and Asia. Minor georeferencing discrepancies between the PRISM3 and the CCSM4 base projections are evident in the North American Rocky Mountains and in the Himalayas (Fig. 1). Following PlioMIP protocol (Haywood et al., 2011) we set Hudson Bay and West Antarctica to $25 \mathrm{~m}$ above sea level. River discharge mapping in the mPWP simulation remains unchanged from present day; drainage across land cells in the emergent Hudson Bay region is routed automatically to the nearest ocean grid cell in the Labrador Sea.

\subsection{Vegetation}

The PRISM3 dataset defines global vegetation using the BIOME4 (Salzmann et al., 2008, 2009) model reconstruction of mPWP plant biome communities. CLM4 uses plant functional types (PFTs) to describe vegetation distributions (Oleson and Bonan 2000; Bonan et al., 2002). Rather than translating the BIOME4 plant biomes to CLM4 plant functional types, we instead spatially correlate the modern BIOME4 
Table 1. Summary of forcings and boundary conditions for the mPWP and 1850 PI control simulations.

\begin{tabular}{lll}
\hline Boundary Condition/Forcing & PI Control & mPWP \\
\hline Experimental design & CMIP5 & PlioMIP Exp. 2 alternate \\
Land/sea mask & Modern & Modern minus Hudson Bay \\
Resolution & $1^{\circ}$ ocn, ice, atm, lnd & $1^{\circ}$ ocn, ice, atm, lnd \\
Topography & Modern & Modern + $\Delta$ Topo (PRISM3) \\
Landcover & Modern & BIOME4 mapped to CLM4-PFTs; PI carbon pools \\
SST, DOT & PI & PI + $\Delta$ (SST, DOT)(PRISM3) \\
Ice sheets & Modern & PRISM3 changes to Greenland and Antarctic ice sheets \\
West Antarctic Ice Sheet (WAIS) & Modern & WAIS replaced by vegetated land at 25 m above MSL \\
Ocean bathymetry & Modern & Modern \\
Ocean gateways & Modern & Modern \\
CO 2 (ppm) & 284.7 & 405 \\
$\mathrm{~N}_{2} \mathrm{O}$ (ppb) & 275.68 & 275.68 \\
$\mathrm{CH}{ }_{4}$ (ppb) & 791.6 & 791.6 \\
Solar constant $\left(\mathrm{W} \mathrm{m}{ }^{-2}\right.$ ) & 1360.89 & 1360.89 \\
Orbital forcing & $1990 \mathrm{AD}$ & $1990 \mathrm{AD}$ \\
Aerosol flux & $1850 \mathrm{AD}$ & $1850 \mathrm{AD}$ \\
Simulation length $(\mathrm{yr})$ & 1300 & 500 \\
Analysis years & $1271-1300$ & $471-500$ \\
\hline
\end{tabular}

biome communities to the modern CLM4/PFT landcover distribution. Using the correlations developed from the modern biome-to-PFT comparison, we spatially extrapolate the CLM4/PFTs to the BIOME4 mPWP biome reconstruction, creating a new mPWP PFT reconstruction for CLM4 that preserves the spatial consistency of modern BIOME4-toCLM4/PFT biogeography (see Lawrence and Chase (2010) for an analogous application of this approach). This method has the advantage of retaining a physical connection to present-day PFT mapping. Soil type distributions are identical to preindustrial.

\subsection{Land ice}

The Greenland land ice reconstruction for the mPWP (Hill et al., 2007) greatly reduces the extent of the Greenland Ice Sheet (Fig. 1). In the Southern Hemisphere (SH), PRISM3 reconstructions suggest the WAIS was absent and ice was redistributed over the East Antarctic Ice Sheet (EAIS) relative to present day. Although the "preferred" PlioMIP experimental boundary condition removes the WAIS and replaces it with ocean, we use the "alternate" protocol and instead lower the WAIS to $25 \mathrm{~m}$ to simulate removal of continental ice. We chose the "alternate" configuration package to avoid extensive modifications to the CCSM4 POP2 ocean grid and bathymetry near the WAIS. We replace land ice with shrubs and arctic grasses over the deglaciated areas of Greenland, WAIS, and EAIS, as prescribed by the BIOME4 plant biome reconstruction (Salzmann et al., 2008).

\subsection{Initialization of mPWP simulation}

We branch from the $1300 \mathrm{yr}$ PI control simulation at model year 801, running a hybrid mPWP simulation with the fully coupled CCSM4 model. We modify the initial temperature state of the full ocean using PRISM3 reconstructed SST and deep ocean temperature (DOT) anomalies (Haywood et al., 2011; Dowsett et al., 2009) in a process analogous to that used to create mPWP topography. We first create SST and DOT anomalies by differencing the PRISM3 ocean temperature reconstruction against modern-day Levitus (mPWP minus Levitus) (Levitus and Boyer, 1994). We then interpolate the reconstructed SST and DOT anomalies from their native $4^{\circ} \times 5^{\circ}$ latitude/longitude grid to the CCSM4 POP2 grid $(384 \times 320$ grid cells $)$ and remap the DOT anomaly from 33 layers to the 60 ocean levels used by POP2 before adding the SST and DOT anomalies to year 801 of the PI control simulation. Ocean salinity and sea ice extent are unchanged from the PI control. To avoid numerical instabilities from restarting the ocean with a modified land/sea mask, we set velocities and surface pressure gradients to zero in the ocean initial files. To initialize the land model, we project the CLM4 initial state from PI model year 801 onto the modified $\mathrm{mPWP}$ land/sea mask. We run the hybrid mPWP simulation for 500 simulated years on Bluefire, an IBM Power6 computer located at the National Center for Atmospheric Research (NCAR) in Boulder, Colorado. 
Table 2. Summary of CCSM4 model response.

\begin{tabular}{|c|c|c|}
\hline Variable & mPWP & $\begin{array}{l}\text { Change } \\
\text { from PI }\end{array}$ \\
\hline Global surface temperature $\left({ }^{\circ} \mathrm{C}\right)$ & 15.9 & 1.9 \\
\hline NH surface temperature $\left(20-90^{\circ} \mathrm{N}\right)\left({ }^{\circ} \mathrm{C}\right)$ & 11.1 & 2.3 \\
\hline SH surface temperature $\left(90-20^{\circ} \mathrm{S}\right)\left({ }^{\circ} \mathrm{C}\right)$ & 8.9 & 2.2 \\
\hline Global surface temperature over land $\left({ }^{\circ} \mathrm{C}\right)$ & 9.6 & 2.4 \\
\hline Global precipitation $\left(\mathrm{mm} \mathrm{day}^{-1}\right)$ & 3.0 & 0.086 \\
\hline Global precipitation over land $\left(\mathrm{mm} \mathrm{day}^{-1}\right)$ & 2.5 & 0.093 \\
\hline Top of atmosphere energy imbalance $\left(\mathrm{W} \mathrm{m}^{-2}\right)$ & 0.02 & 0.14 \\
\hline Global sea surface salinity (psu) & 34.21 & -0.14 \\
\hline Global sea surface temperature $\left({ }^{\circ} \mathrm{C}\right)$ & 21.6 & 1.2 \\
\hline NH Sea ice area $\left(10^{6} \mathrm{~km}^{2}\right)$ & 9.0 & $-2.7(-23 \%)$ \\
\hline SH Sea ice area $\left(10^{6} \mathrm{~km}^{2}\right)$ & 11.9 & $-5.1(-30 \%)$ \\
\hline Niño $3.4 \sigma\left({ }^{\circ} \mathrm{C}\right)$ & 0.82 & -0.19 \\
\hline
\end{tabular}

\section{Results}

\subsection{Approach to equilibrium}

Globally averaged mean annual air temperature (Fig. 2a) warms for the first $140 \mathrm{yr}$ of the simulation, then stabilizing, after a small overshoot, by year 180 at $15.9^{\circ} \mathrm{C}-1.9^{\circ} \mathrm{C}$ warmer than the PI control. The initial ocean response was strongly affected by the warm DOT anomaly applied to the full ocean. The result was a reduction of the Atlantic meridional overturning circulation (AMOC), which immediately decreased from an initial strength of 24-17 Sv (Fig. 2b). The overturning circulation recovered within 135 model years, weakly overshooting to a maximum of $28 \mathrm{~Sv}$ before stabilizing at $26 \mathrm{~Sv}$, similar to the preindustrial CCSM4 AMOC strength. Globally averaged ocean temperature continues to warm by $\sim 0.025^{\circ} \mathrm{C}$ per century (Fig. 2c), which is similar in magnitude, although opposite in sign, to the PI control simulation, and indicates that the deep ocean is still coming into equilibrium, a process that takes thousands of years.

\subsection{Surface air temperature}

Simulated annual and seasonal air temperatures demonstrate warming globally (Fig. 3) relative to the preindustrial control (stippling indicates results are not statistically significant at $95 \%$ ). Globally averaged mean annual temperature (MAT) increases by $1.9^{\circ} \mathrm{C}$ (Table 2) with enhanced warming over land $\left(2.4^{\circ} \mathrm{C}\right)$ relative to oceans. Zonally averaged MAT increases $>5^{\circ} \mathrm{C}$ at high latitudes, while tropical MAT warms by only $\sim 1^{\circ} \mathrm{C}$. Seasonal warming at high latitudes is such that zonally averaged boreal and austral wintertime temperatures increase by $\sim 6^{\circ} \mathrm{C}$, while summertime temperatures warm by $4-5^{\circ} \mathrm{C}$. High-latitude warming is greater in the Northern Hemisphere (NH).

Fine-scale temperature variability across North America and Asia is caused by differences between the PRISM3 and CCSM4 base projections (Fig. 1). Surface warming over East Antarctic reflects changes to the EAIS topographic profile
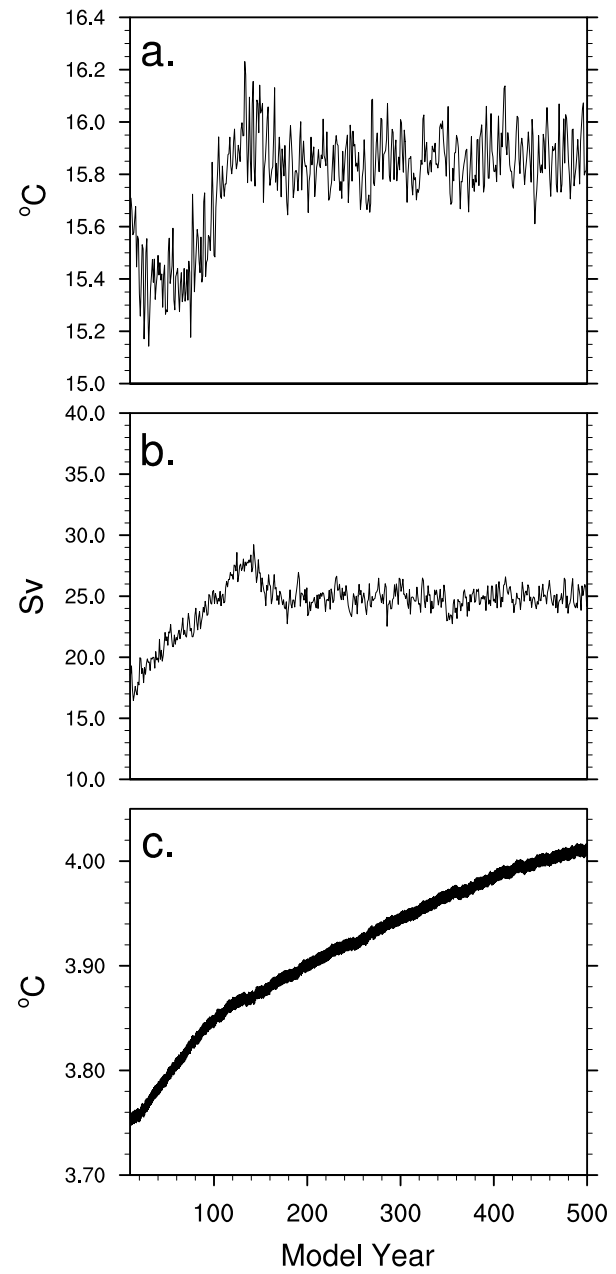

Fig. 2. Time series plots of simulated annual mPWP (a) global surface air temperature, (b) Atlantic meridional overturning circulation, and (c) volume-integrated, global ocean temperature.

(Fig. 1), while warming over Greenland, West Antarctica, and coastal East Antarctica reflects the dual effects of lowered elevation and landcover conversion from land ice to arctic grasses. The northward expansion of broadleaf and needleleaf trees in BIOME4 and consequent lowering of surface albedo contributes to wintertime warming across northeastern Siberia (Fig. 3). Relative wintertime cooling across southern Siberia (not significant) is similarly related to a conversion from forests to grassland, with a consequent increase in surface albedo. Relative warming and cooling over Hudson Bay is the result of the land/sea mask conversion from ocean to land.

\subsection{Precipitation}

Globally averaged mean precipitation increased slightly $\left(0.086 \mathrm{~mm} \mathrm{day}^{-1}\right)$ in the mPWP experiment, with a relatively greater increase over land $\left(0.093 \mathrm{~mm} \mathrm{day}^{-1}\right)$ (Table 2). Figure 4 shows annual and seasonal precipitation change. The 


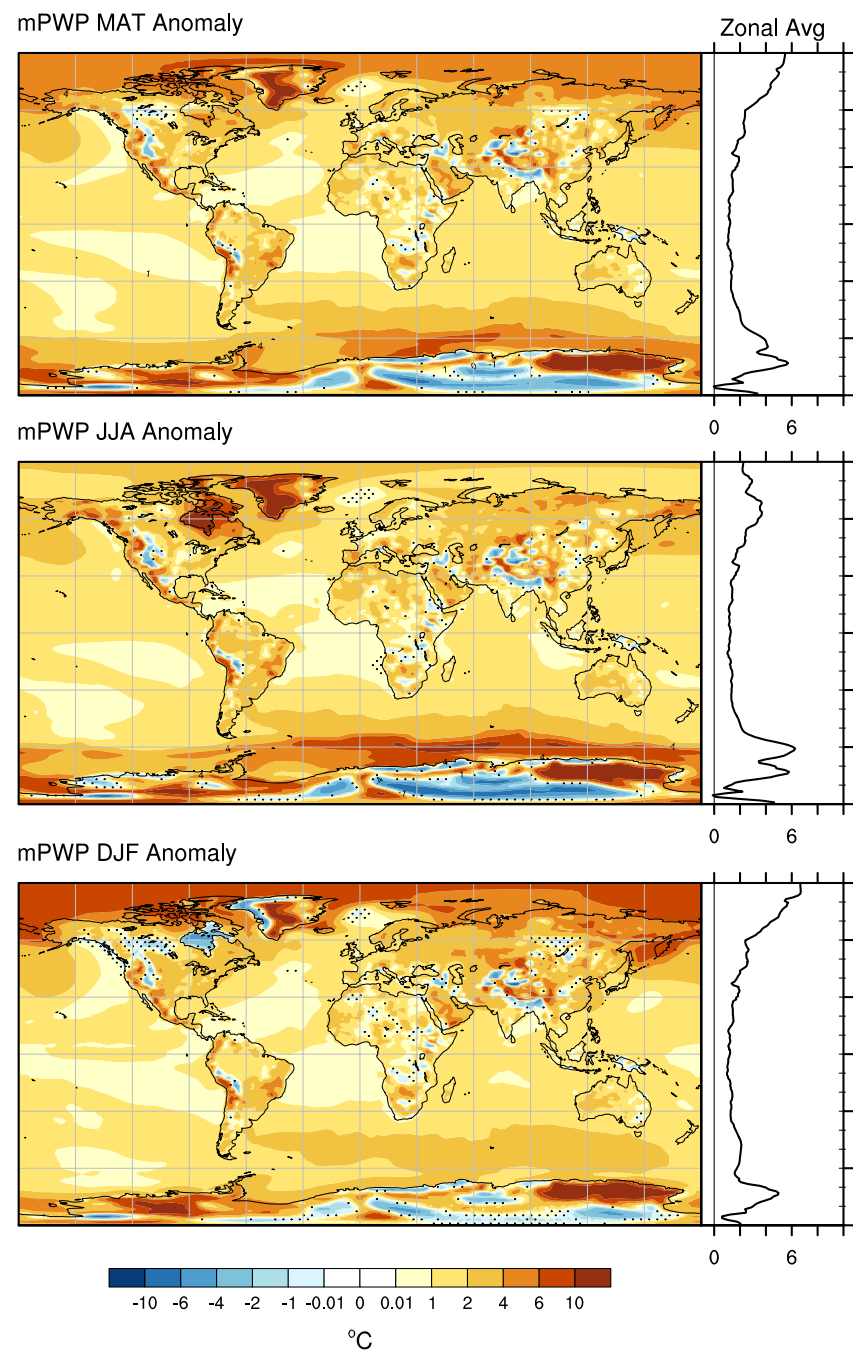

Fig. 3. CCSM4 simulated annual and seasonal mPWP surface temperature change $\left({ }^{\circ} \mathrm{C}\right)$ from PI control; stippling indicates results are not statistically significant at $95 \%$ level. Zonally averaged temperature change (mPWP minus control) is plotted in the side panels.

pattern of seasonal precipitation indicates a northward shift of the Intertropical Convergence Zone (ITCZ) in response to enhanced NH warming of subtropical SSTs (Fig. 5). Boreal summer precipitation (June-July-August; JJA) increases by $>2 \mathrm{~mm} \mathrm{day}^{-1}$ in the eastern equatorial Pacific Basin, the Arabian and Solomon seas, and the monsoon regions of northern Africa and India. JJA precipitation decreases by $1 \mathrm{~mm} \mathrm{day}^{-1}$ over Siberia and parts of North and South America. Precipitation increases significantly in austral summer (December-January-February; DJF) by $1.5 \mathrm{~mm} \mathrm{day}^{-1}$ over equatorial Africa, the Bay of Bombay, South China Sea, and Papua New Guinea and the Amazon monsoon region. DJF rainfall decreases by $2-4 \mathrm{~mm}_{\text {day }}{ }^{-1}$ over the Brazilian Highlands.
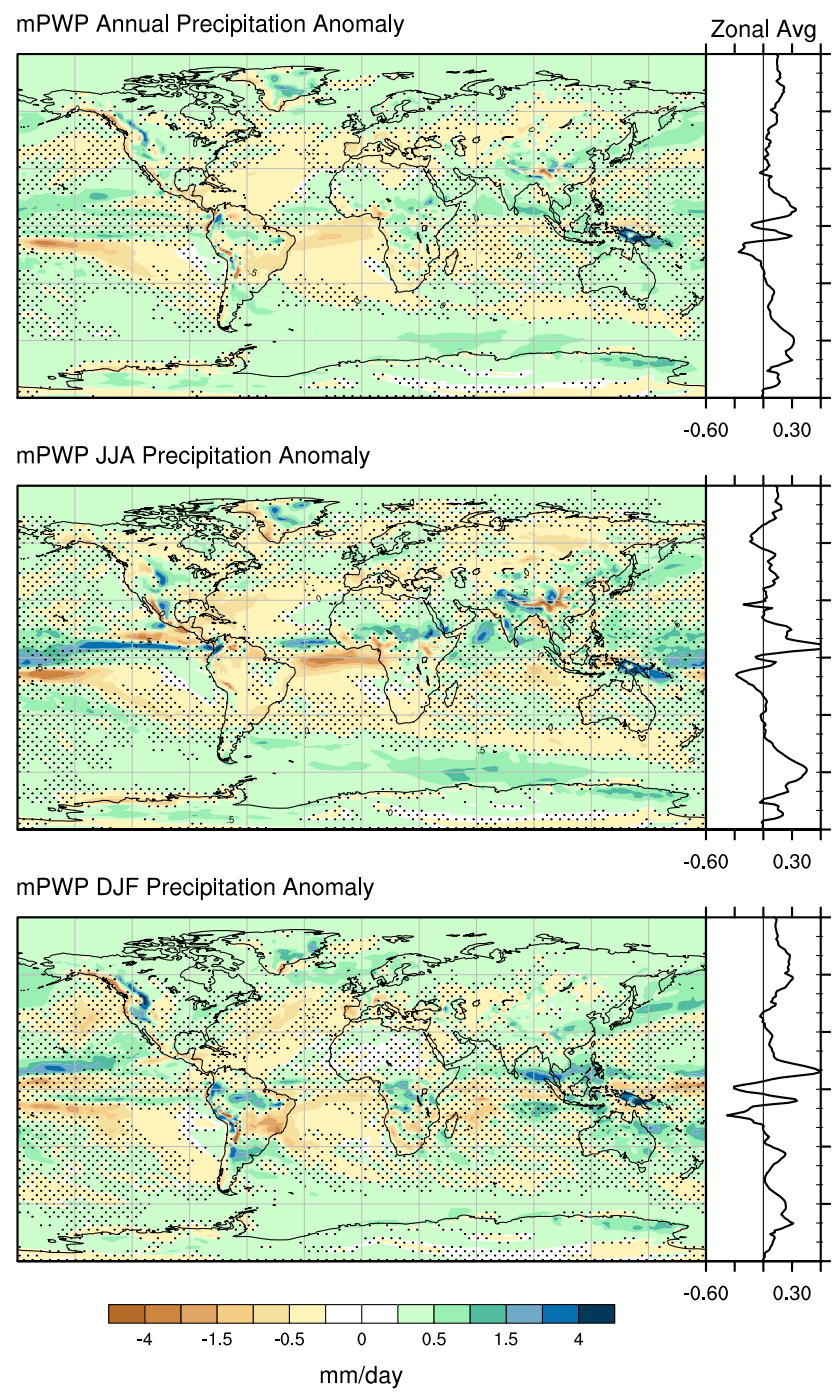

Fig. 4. CCSM4 simulated annual and seasonal mPWP precipitation change $\left(\mathrm{mm} \mathrm{day}^{-1}\right)$ from PI control; stippling indicates results are not statistically significant at $95 \%$ level. Zonally averaged precipitation change (mPWP minus control) is plotted in the side panels.

\subsection{Sea surface temperature and salinity}

We compare the mPWP results against the PRISM3 proxy SST reconstructions (Dowsett et al., 2010). In the North Pacific, CCSM4 SST warms by $2-4{ }^{\circ} \mathrm{C}$; proxy indicators suggest $0-4^{\circ} \mathrm{C}$ change along the eastern and southern Aleutian Islands and up to $\sim 6^{\circ} \mathrm{C}$ warming off the west coast of North America (Fig. 5). The model correctly captures warming (1$2{ }^{\circ} \mathrm{C}$ ) in the eastern equatorial Pacific Basin, but falls short of the $2-4{ }^{\circ} \mathrm{C}$ warming indicated by proxy reconstructions in the equatorial upwelling region. Similarly, the model correctly replicates the sign but not the magnitude of warming seen in proxy records along the northwest coast of Africa. CCSM4 warming in the western Pacific of $2-4{ }^{\circ} \mathrm{C}$ compares well with 
mPWP sea surface temperature
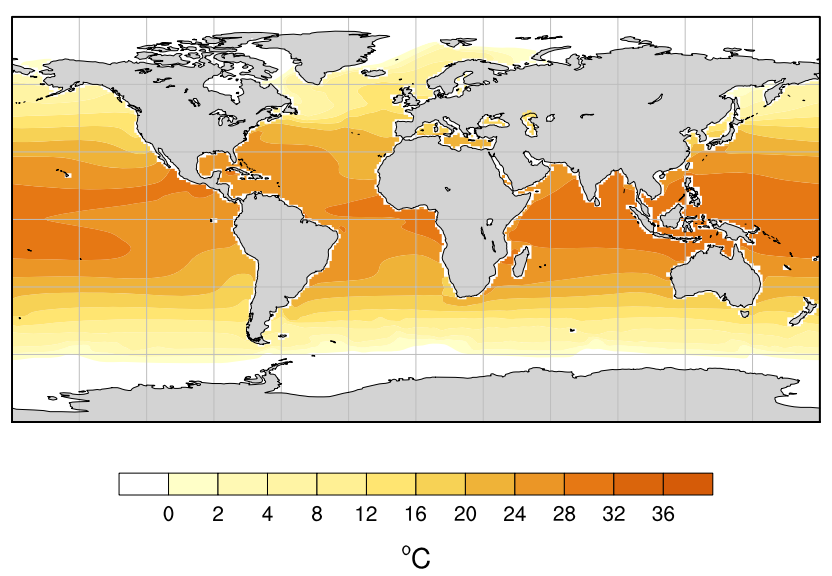

Sea surface temperate change

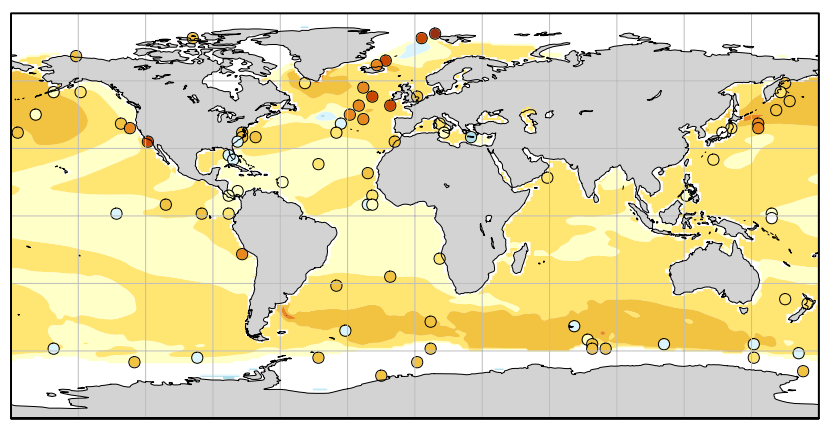

$\begin{array}{llllllllllllll}-10 & -6 & -4 & -2 & -1 & -0.01 & 0 & 0.01 & 1 & 2 & 4 & 6 & 10\end{array}$

${ }^{\circ} \mathrm{C}$

Fig. 5. CCSM4 simulated mPWP SST $\left({ }^{\circ} \mathrm{C}\right)$ (top) and change from PI control (bottom). White regions indicate sea ice in the mPWP simulation (top) and both the mPWP and PI simulations (bottom). Proxy data are plotted as open circles; color code indicates temperature change $\left({ }^{\circ} \mathrm{C}\right)$ from present day.

reconstructed records east of the Kamchatka Peninsula, but falls short of the $4-6^{\circ} \mathrm{C}$ of warming indicated further south off the Kuril Islands. CCSM4 SSTs in the North Atlantic warm by $2-4{ }^{\circ} \mathrm{C}$ near the southern tip of Greenland, but do not capture the $>10^{\circ} \mathrm{C}$ of warming suggested by proxy reconstructions. Two limited regions in the North Atlantic cool by $1-2{ }^{\circ} \mathrm{C}$ in CCSM4, though not significantly. Proxy reconstructions in the Southern Ocean show regional heterogeneity with some proxies signaling $\sim 1{ }^{\circ} \mathrm{C}$ cooling, and other areas pointing to as much as $3^{\circ} \mathrm{C}$ warming. CCSM4 temperatures in the Southern Ocean warm by $2-4^{\circ} \mathrm{C}$ in the South Atlantic and Indian Ocean sectors. Simulated temperatures in the South Pacific increase by $<2{ }^{\circ} \mathrm{C}$.

Sea surface salinity (Fig. 6) indicates freshening in the polar oceans, where contraction in thickness and extent of sea ice in the mPWP simulation signals an overall reduction in brine rejection, and a consequent fall in sea surface salinity relative to preindustrial. A low-salinity plume from the
mPWP sea surface salinity

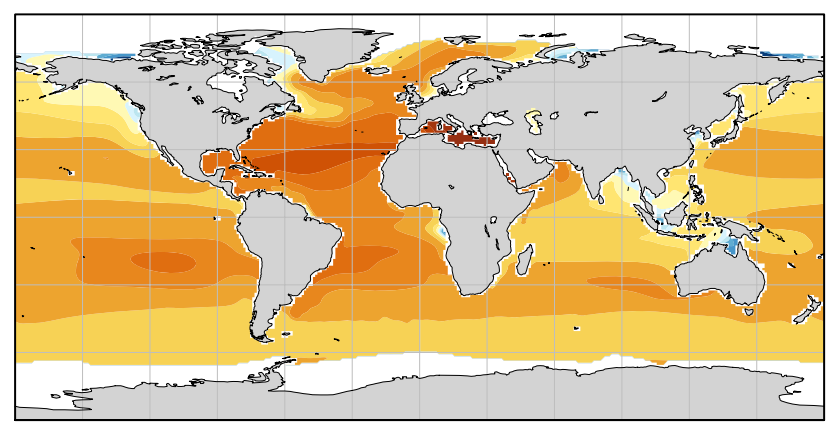

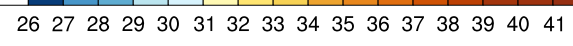
psu

Sea surface salinity change

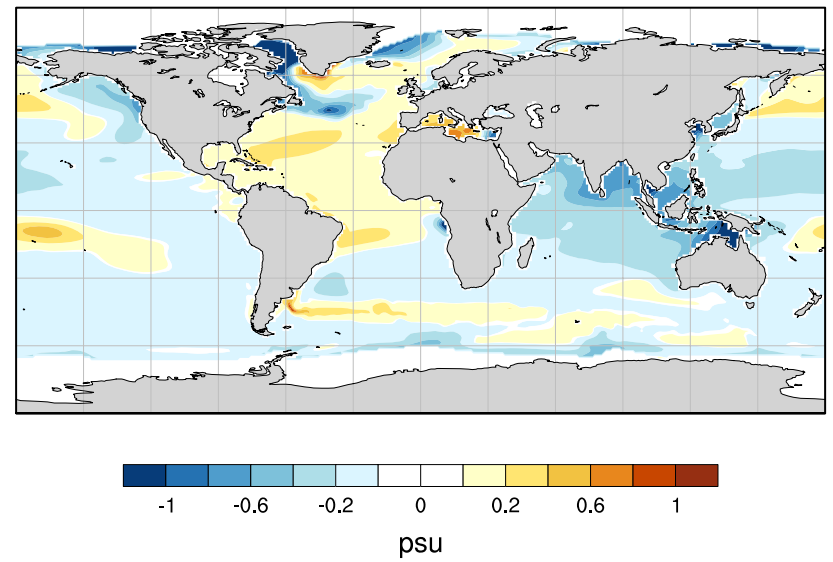

Fig. 6. CCSM4 simulated sea surface salinity (top) and change from PI control (bottom). White polar regions indicate sea ice in the mPWP simulation (top) and both the MPWP and PI simulations (bottom).

Labrador Sea is carried southward by the Labrador Current, entrained off the coast of Newfoundland and carried east and south along the northern edge of the North Atlantic Drift. Conversely, an increase in the evaporation minus precipitation (E-P) in the tropical Atlantic Ocean and midlatitude North Pacific Ocean results in saltier Gulf Stream and East Pacific currents. Increased tropical precipitation and runoff off Southeast Asia lower sea surface salinity from the South China Sea and the Bay of Bengal to the Arafura Sea and the north coast of Australia. Increased runoff from the Pacific Northwest in North America lowers salinity in the Gulf of Alaska.

\subsection{Ocean circulation}

The simulated mPWP AMOC is comparable to the PI control (Fig. 7a,b). Positive/negative stream function strength indicates clockwise/counterclockwise flow; clockwise flow 


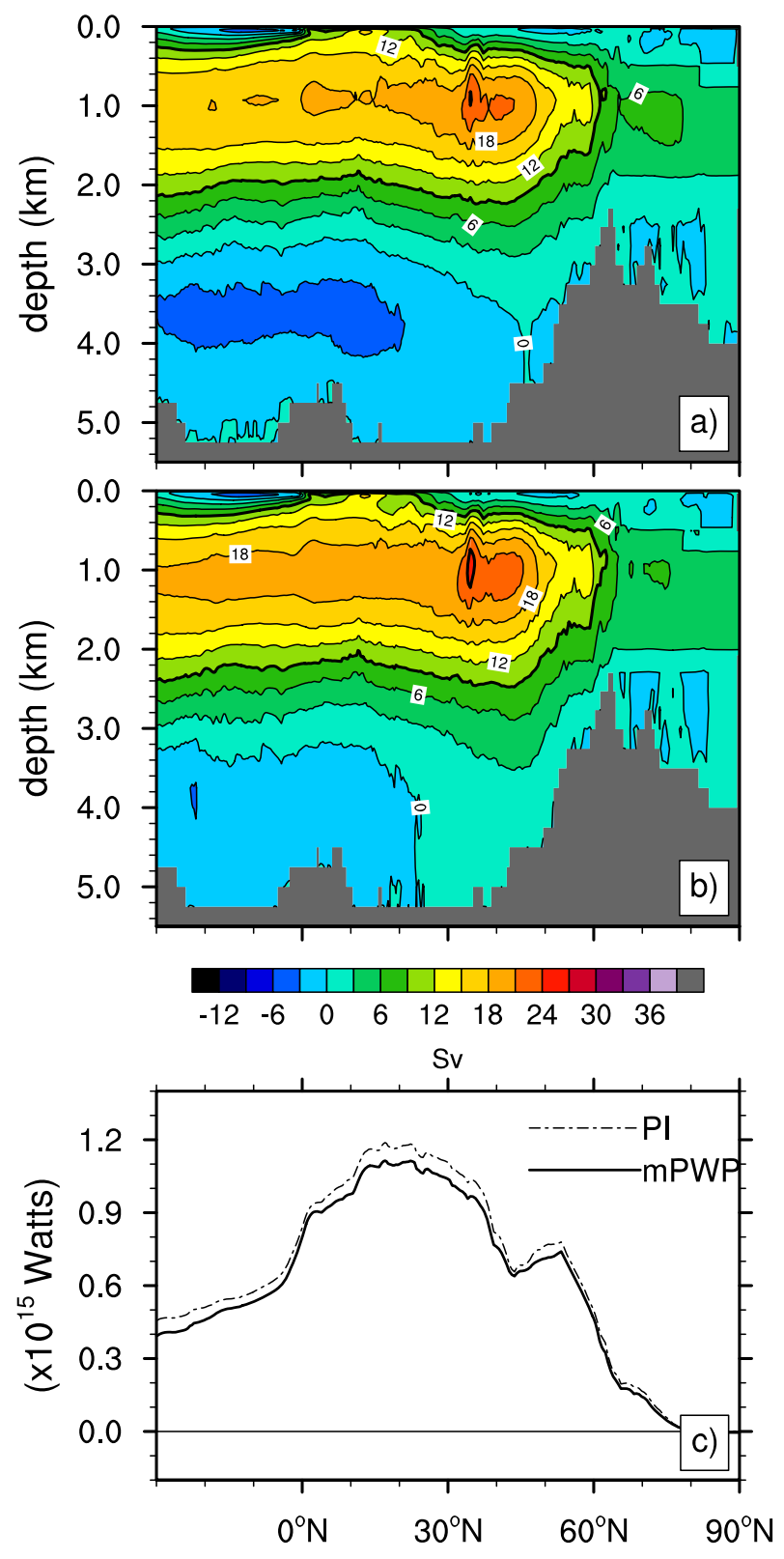

Fig. 7. Eulerian mean meridional overturning circulation (Sv) in the Atlantic Ocean basin for (a) the mPWP, and (b) 1850 PI control; contour interval is $3 \mathrm{~Sv}$. (c) Northward ocean heat transport $\left(\times 10^{15}\right.$ Watts) in the Atlantic Basin for the mPWP (solid) and the PI control (dashed).

in the North Atlantic tracks the northward cycling of warm surface water; counterclockwise flow tracks northward flowing deep water from the Southern Ocean. In the mPWP simulation, Southern Ocean water is moving with roughly similar velocity and strength as in the preindustrial simulation. However, Southern Ocean flow moves much farther north in the mPWP simulation with Antarctic bottom water filling the deep basin up to sill depth.
Northward ocean heat transport in the Atlantic Basin for the simulated mPWP (Fig. 7c) is indistinguishable from preindustrial. This unremarkable response is likely a factor in why the model does not capture the magnitude of warming indicated by North Atlantic temperature proxies. Simulated NH SSTs do not warm enough in the mPWP, particularly in the North Atlantic, whereas SH SSTs are too warm, suggesting that enhanced northward ocean heat transport might redistribute enough ocean heat to bring CCSM4 SSTs more in line with proxy evidence.

\subsection{Sea ice}

The sea ice extent of mPWP (areal \%) and thickness (not shown) decrease in both hemispheres (Fig. 8). Overall, summertime sea ice extent is reduced by $\sim 23 \%$ in the Arctic, particularly along the coastal continental shelf, as well as in the Labrador, Greenland and Norwegian seas, where areal extent is reduced by $>25 \%$ (Fig. 8). Wintertime sea ice extent (not shown) is reduced by a modest $4 \%$ across the Arctic, but drops dramatically in the Pacific Basin, where spatial maps indicate a $>20 \%$ reduction in the Bering Sea and the Sea of Okhotsk. Similar declines are seen in the Barents Sea, off the southeast coast of Greenland, and in the Labrador Sea along the coast of Newfoundland. Winter and summertime sea ice thickness (not shown) is reduced by as much as $2 \mathrm{~m}$ across the Arctic, with even greater thinning (2-4 m) off the northern coasts of Greenland and the Queen Elizabeth Islands. Wintertime sea ice thins by up to a meter in the Bering Sea and Sea of Okhotsk, and in the Labrador Sea south to Newfoundland. The PRISM3 sea ice reconstruction (Dowsett, 2007; Robinson et al., 2008; Dowsett and Robinson, 2009) used by the PlioMIP AGCM Experiment 1 (Haywood, 2010) prescribes an ice-free Arctic Ocean during boreal summer. The CCSM4 simulation of the mPWP shows diminished but persistent seasonal sea ice cover for JulyAugust-September (JAS).

In the SH, average summertime sea ice extent around Antarctica decreases by $\sim 30 \%$. Regionally, summer sea ice extent increases slightly $(<5 \%)$ in the Weddell Sea and in isolated pockets of the Ross and Bellingshausen seas and in Prydz Bay (5-15\%). Wintertime sea ice extent increases by up to $10 \%$ in these same areas, but decreases by more than $30 \%$ within the distal third of the seasonal ice pack. Both summer and wintertime sea ice thins by $1.2 \mathrm{~m}$ close to the continent and by $0.4-0.8 \mathrm{~m}$ across the ice pack (not shown). Conversely, both summer and winter sea ice thickens along the edge of the Ronne Ice Shelf in the Weddell Sea, along the west coast of the Antarctic Peninsula, the eastern coast of the Ross Sea and along the edge of the Amery Ice Shelf in Prydz Bay. 

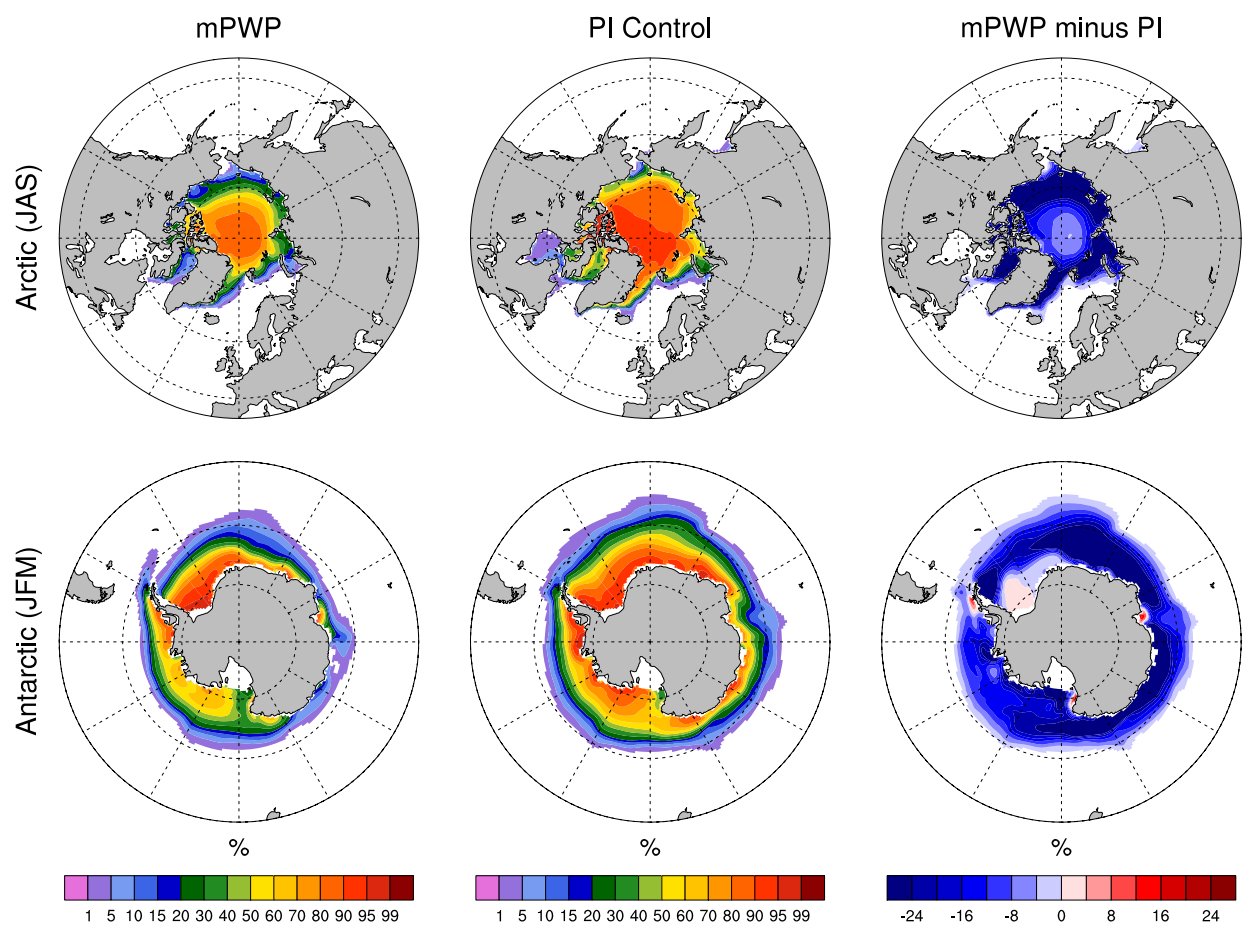

Fig. 8. Spatial maps of CCSM4 simulated Northern Hemisphere (July-August-September; JAS) (top) and Southern Hemisphere (JanuaryFebruary-March; JFM) (bottom) mean sea ice area (\%) for the mPWP, the 1850 PI control, and their difference (mPWP minus PI).

\subsection{ENSO}

The mPWP simulation of Niño3.4 is similar to the preindustrial control in seasonal cycle and dominant 3-6 yr periodicity. However, the Niño3.4, estimated over the last $300 \mathrm{yr}$ of the mPWP, is roughly $20 \%$ weaker $(\sigma=0.82)$ compared to the PI $(\sigma=1.01)$, with extended periods of relative quiescence of up to $150 \mathrm{yr}$ (Fig. 9) compared to similar intervals with only half the duration in the preindustrial. The model does simulate mPWP warming in the eastern equatorial Pacific Basin, signaling a relaxation of the zonal SST gradient similar to the response found in the CCSM4 abrupt $4 \times \mathrm{CO}_{2}$ simulation (Brady et al., 2013), which also has a weakened Niño3.4 $(\sigma=0.75)$.

\section{Comparison to data}

Temperature reconstructions indicate that globally averaged MAT was $2-3^{\circ} \mathrm{C}$ warmer during the mPWP and as much as $15-20^{\circ} \mathrm{C}$ warmer at high latitudes, particularly the Arctic (Ballantyne, 2010). In our CCSM4 mPWP simulation, globally averaged mPWP surface temperatures increase by $1.9^{\circ} \mathrm{C}$ relative to preindustrial (Table 2 ), comparing favorably with the reconstructed global average. However, simulated temperatures are conspicuously at odds with proxy records in several critical areas when we plot SST proxy data against corresponding CCSM4 annual SSTs from the nearest latitude/longitude grid cell, and partition the results by region. Figure 10 shows that, in general, CCSM4 overestimates SST warming in the SH extratropics by $1-4^{\circ} \mathrm{C}$. Conversely, CCSM4 SSTs in the NH extratropics fail to capture the extent of warming expected, particularly in the North Atlantic, where proxy estimates exceed model temperatures by as much as $7^{\circ} \mathrm{C}$. The model shows a uniform SST increase of $\sim 1{ }^{\circ} \mathrm{C}$ in the tropics, but does not capture the $2-4^{\circ} \mathrm{C}$ of warming indicated by proxy reconstructions. The lack of increase in northward ocean heat transport in the Atlantic Basin (Fig. 7) is consistent with the weaker than expected temperature response in the North Atlantic and warmer than expected SSTs in the SH.

\section{Relevance to future projections}

Proxy temperature reconstructions from the mPWP Arctic point to a reduced equator-to-pole temperature gradient. In Fig. 11 we plot the polar amplification, which is the zonally averaged mean annual surface temperature change for the mPWP simulation normalized by the global mean annual temperature change for the same period. We show the mPWP response together with the results from a CCSM4 $\mathrm{CO}_{2}$ sensitivity simulation where $\mathrm{CO}_{2}$ was abruptly elevated to four times the preindustrial $\mathrm{CO}_{2}$ concentration $\left(4 \times \mathrm{CO}_{2}\right)$. The forcing for the mPWP includes changes to the land/sea mask over Hudson Bay, changes to the size and extent of the Greenland and Antarctic Ice Sheets, and widespread vegetation shifts, along with an estimated radiative forcing of 


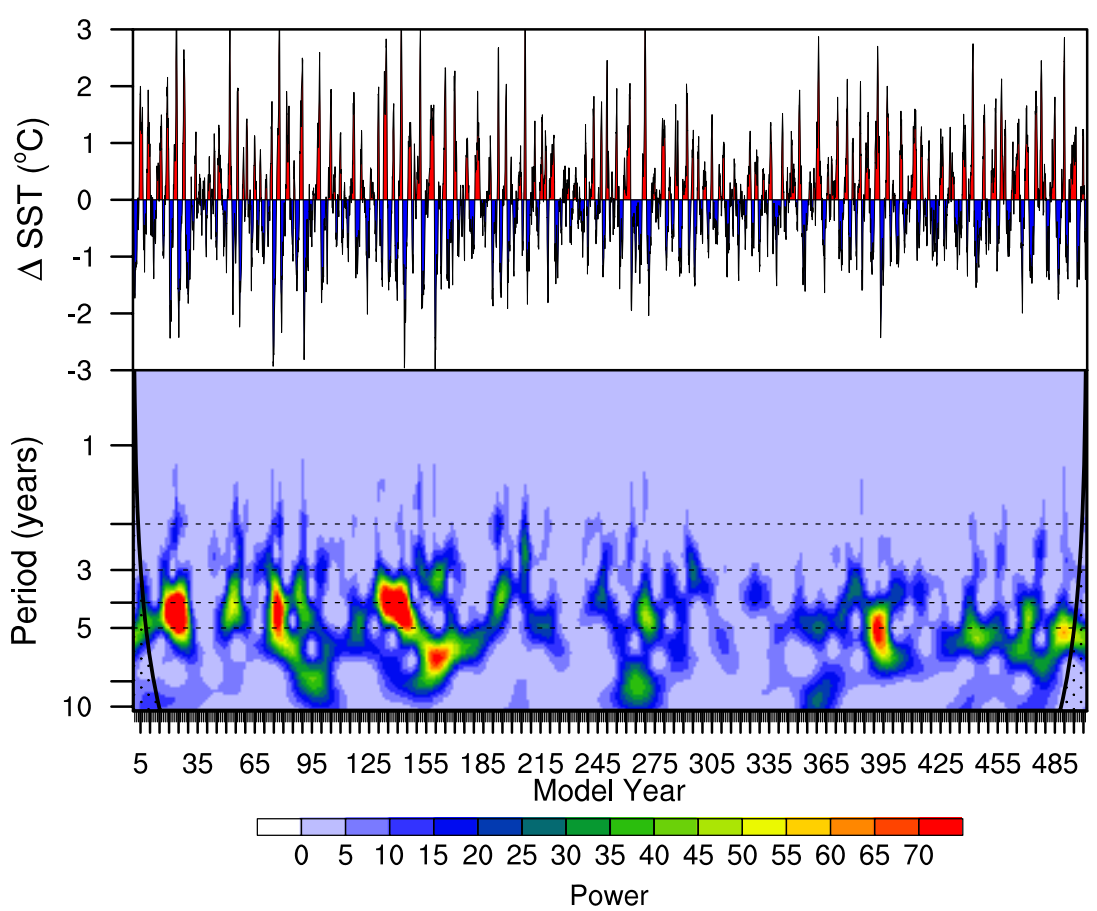

Fig. 9. The Niño3.4 index $\left({ }^{\circ} \mathrm{C}\right)$ from the mPWP simulation (top) and the corresponding wavelet power spectrum (bottom).
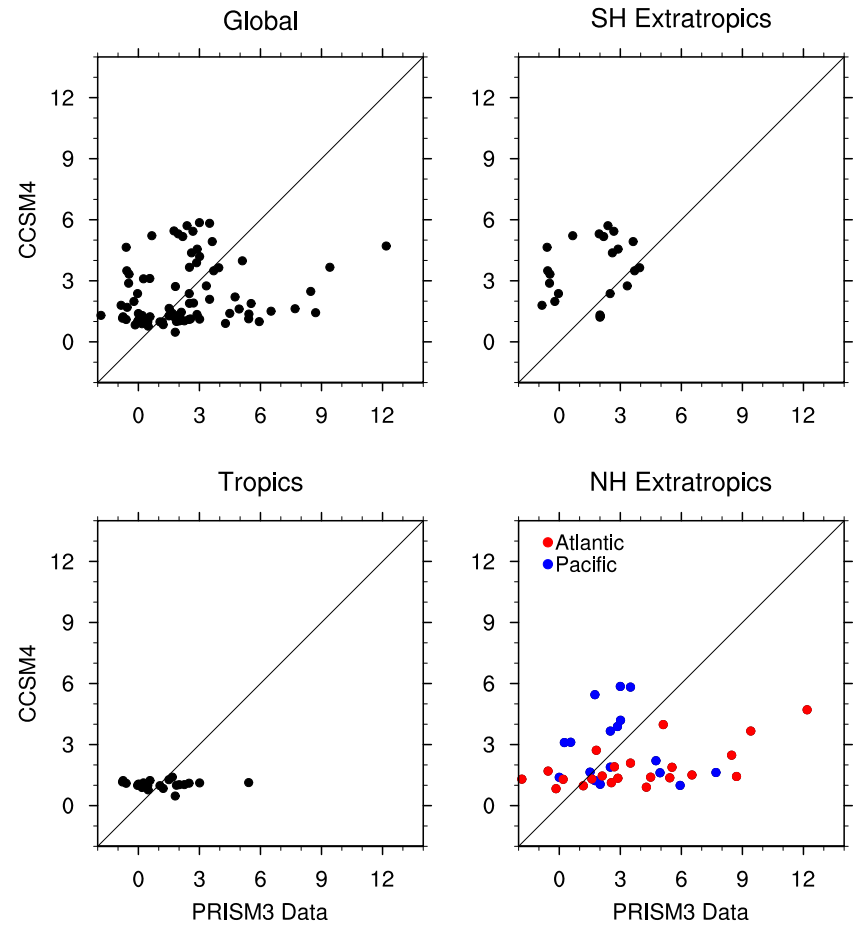

Fig. 10. PRISM3 reconstructed annual SST plotted against CCSM4 mPWP annual SST for the same latitude/longitude grid cell.

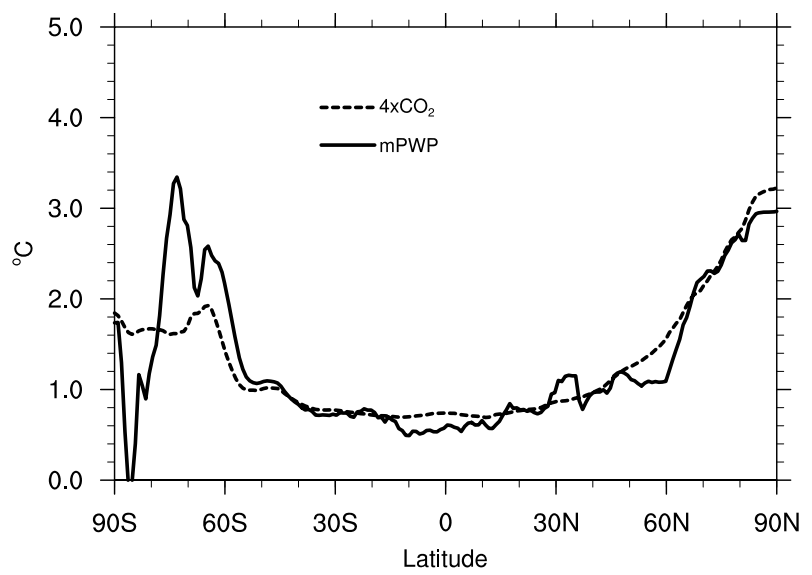

Fig. 11. Zonally averaged MAT anomaly normalized by the global MAT anomaly for the mPWP (solid line), and abrupt $4 \times \mathrm{CO}_{2}$ scenario simulations with CCSM4 (dashed line).

$1.9 \mathrm{~W} \mathrm{~m}^{-2}$ from elevated $\mathrm{CO}_{2}$. The $4 \times \mathrm{CO}_{2}$ simulation has an estimated radiative forcing from $\mathrm{CO}_{2}$ alone of $7.4 \mathrm{~W} \mathrm{~m}^{-2}$, relative to the PI. The mPWP simulation has a comparable latitudinal response to the CCSM $44 \times \mathrm{CO}_{2}$ experiment; both simulations show a muted tropical response, with polar amplification of $\sim 3$ times the global temperature change. The exaggerated warming/cooling signal in the MPWP SH temperature is caused by the removal of the WAIS and by elevation changes over the EAIS relative to PI. 


\section{mPWP minus PI Control (JAS)}

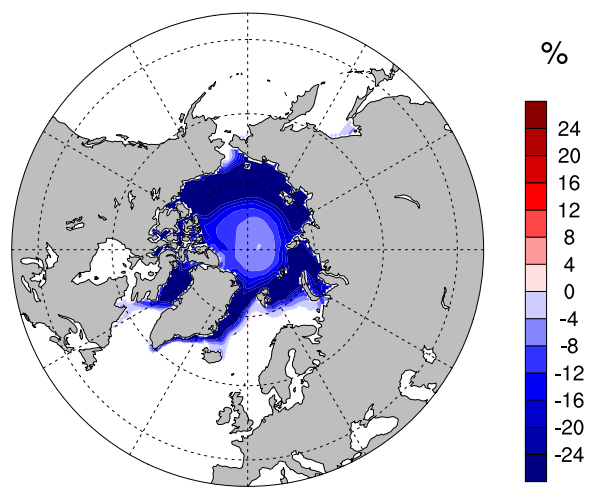

RCP2.6 minus end of 20th Century (JAS)

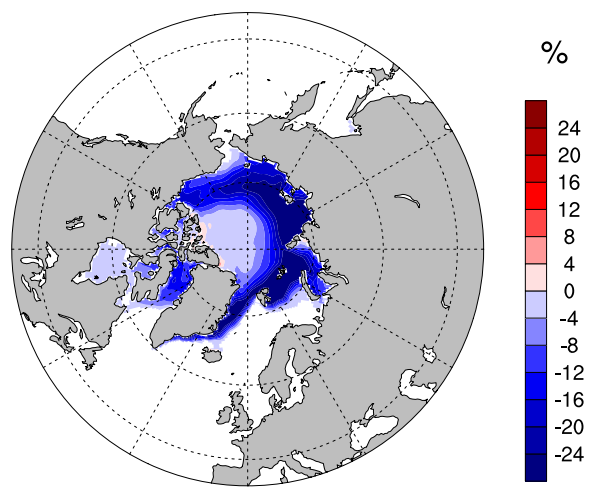

Fig. 12. Spatial maps of the change in NH JAS sea ice area (\%) in the mPWP simulation (mPWP minus PI control) (top). Change in NH JAS sea ice area (\%) in the IPCC RCP2.6 scenario (RCP2.6, years 2080-2099, minus 20th century, years 1980-1999) (bottom).

We compare mPWP Arctic JAS sea ice concentration against the CCSM4 CMIP5 RCP2.6 simulation (radiative forcing $=2.6 \mathrm{~W} \mathrm{~m}^{-2}$ ) in Fig. 12. We show the RCP2.6 ensemble member with the greatest reduction in $\mathrm{NH}$ sea ice extent, and compare years 2080-2099 from RCP2.6 against years 1980-1999 from the end of the 20th century simulation. JAS arctic sea ice reduction is greater in the mPWP simulation (relative to the PI control), than in the RCP2.6 simulation (relative to the end of the 20th century).

\section{Summary}

We present results from a $500 \mathrm{yr}$ simulation of the mPWP using the CCSM4 fully coupled model as part of the PlioMIP. The mPWP was the last prolonged period in Earth history when $\mathrm{CO}_{2}$ concentrations were similar to present day, resulting in global mean temperatures that were $2-3^{\circ} \mathrm{C}$ warmer than modern and polar temperatures that were as much as $20^{\circ} \mathrm{C}$ warmer. The experimental design for the CCSM4 simulation follows the "alternate" PlioMIP protocol for Experiment 2. Results from the CCSM4 simulation show a $1.9^{\circ} \mathrm{C}$ increase in globally averaged mean annual surface temper- ature relative to the CCSM4 1850 PI control, with zonally averaged temperature increases of $6^{\circ} \mathrm{C}$ at high latitudes and polar amplification of 3 times the global warming. Highlatitude warming is greater in the $\mathrm{NH}$ than $\mathrm{SH}$. Average surface temperature over land increases by $2.4^{\circ} \mathrm{C}$; globally averaged sea surface temperature increases by $1.2^{\circ} \mathrm{C}$. Global precipitation increases slightly by $0.09 \mathrm{~mm} \mathrm{day}^{-1}$ and the ITCZ shifts northward, reflecting greater warming in NH SSTs. Areal sea ice extent decreases in both hemispheres, with a greater decrease in the SH. Arctic sea ice in CCSM4 thins by $>2 \mathrm{~m}$, but persists through boreal summer (JAS). The model correctly captures warming in the eastern Pacific Basin, signaling a relaxation of the zonal SST gradient, but fails to capture the magnitude of warming in equatorial upwelling areas. Northward ocean heat transport in the Atlantic Basin is indistinguishable from the control. CCSM4 produces weaker SST warming than reconstructed in the North Atlantic, and greater SST warming than reconstructed in the SH. This bipolar bias suggests an increase in northward oceanic heat transport could bring CCSM4 into better agreement with SST reconstructions.

Acknowledgements. We thank the PRISM group for providing the mPWP datasets for PlioMIP. We also thank the large community of scientists and engineers who contribute to the development of the Community Earth System Model (CESM), including CCSM4. The CESM project is supported by the National Science Foundation and the Department of Energy. The National Center for Atmospheric Research is sponsored by the National Science Foundation, and this work was also supported through grant NSF-EAR-1237211. Computing resources were provided by the Climate Simulation Laboratory (CSL) at NCAR's Computational and Information Systems Laboratory (CISL), which is sponsored by the National Science Foundation and other agencies. This research was enabled by CISL compute and storage resources. Bluefire, a 4064-processor IBM Power6 resource with a peak of 77 TeraFLOPS provided more than 7.5 million computing hours, the GLADE high-speed disk resources provided 0.4 petabytes of dedicated disk, and CISL's 12-PB HPSS archive provided over 1 petabyte of storage in support of this research project.

Edited by: D. Lunt

\section{References}

Amante, C. and Eakins, B. W.: ETOPO1 1 Arc-Minute Global Relief Model: Procedures, Data Sources and Analysis, National Geophysical Data Center, NESDIS, NOAA, U.S. Department of Commerce, Boulder, CO, August 2008.

Ballantyne, A. P., Greenwood, D. R., Sinninghe Damste, J. S., Czank, A. Z., Eberle, J. J., and Rybczynski, N.: Significantly warmer Arctic surface temperatures during the Pliocene indicated by multiple independent proxies, Geology, 38, 603-606, doi:10.1130/G30815.1, 2010. 
Bonan, G. B., Levis, S., Kergoat, L., and Oleson, K. W.: Landscapes as patches of plant functional types: An integrating concept for climate and ecosystem models, Global Biogeochem. Cy., 16, 5.1-5.23 doi:10.1029/2000GB001360, 2002.

Brady, E. C., Otto-Bliesner, B. L., Kay, J. E., and Rosenbloom, N. A.: Sensitivity to Glacial Forcing in the CCSM4, J. Climate, 26, 1901-1925, doi:http://dx.doi.org/10.1175/JCLI-D-1100416.1, 2013.

Branstetter, M. L. and Famiglietti, J. S.: Testing the sensitivity of GCM-simulated runoff to climate model resolution using a parallel river transport algorithm, Preprints, 14th Conference on Hydrology, Dallas, TX, USA, American Meteorological Society, 6B.11, 1999.

Briegleb, B. P., Danabasoglu, G., and Large, W. G.: An overflow parameterization for the ocean component of the Community Climate SystemModel, NCAR Technical Note NCAR/TN481+STR, doi:10.5065/D69K4863, 2010.

Cogley, J. G.: GGHYDRO - Global Hydrographic Data Release 2.0, Trent Climate Note 91-1, Dept. Geography, Trent University, Peterborough, Ontario, 1991.

Danabasoglu, G., Large, W. G., Tribbia, J. J., Gent, P. R., Briegleb, B. P., and McWilliams, J. C.: Diurnal coupling in the tropical oceans of CCSM3, J. Climate, 19, 2347-2365, doi:10.1175/JCLI3739.1, 2006.

Danabasoglu, G., Large, W. G., and Briegleb, B. P.: Climate impacts of parameterized Nordic Sea overflows, J. Geophys. Res., 115, C11005, doi:10.1029/2010JC006243, 2010.

Danabasoglu, G., Bates, S. C., Briegleb, B. P., Jayne, S. R., Jochum, M., Large, W. G., Peacock, S., and Yeager, S. G.: The CCSM4 Ocean Component, J. Climate, 25, 1361-1389, doi:10.1175/JCLI-D-11-00091.1, 2012.

Deser, C., Phillips, A. S., Tomas, R. A., Okumura, Y. M., Alexander, M. A., Capotondi, A., and Scott, J. D.: ENSO and Pacific Decadal Variability in the Community Climate System Model Version 4, J. Climate, 25, 2622-2651, doi:10.1175/JCLI-D-1100301.1, 2012.

Dowsett, H. J.: Faunal re-evaluation of Mid-Pliocene conditions in the western equatorial Pacific, Micropaleontology, 53, 447-456, 2007.

Dowsett, H. J. and Robinson, M. M.: Mid-Pliocene equatorial Pacific sea surface temperature reconstruction: a multiproxy perspective, Philos. T. R. Soc. A, 367, 109-126, doi:10.1098/rsta.2008.0206, 2009.

Dowsett, H. J., Robinson, M. M., and Foley, K. M.: Pliocene threedimensional global ocean temperature reconstruction, Clim. Past, 5, 769-783, doi:10.5194/cp-5-769-2009, 2009.

Dowsett, H. J., Robinson, M. M., Stoll, D. K., and Foley, K. M.: Mid-Piacenzian mean annual sea surface temperature analysis for data-model comparisons, Stratigraphy, 7, 189-198, 2010.

Gent, P. R., Danabasoglu, G., Donner, L. J., Holland, M. M., Hunke, E. C., Jayne, S. R., Lawrence, D. M., Neale, R. B., Rasch, P. J., Vertenstein, M., Worley, P. H., Yang, Z.-L., and Zhang, M.: The Community Climate System Model Version 4, J. Climate, 24, 4973-4991, doi:10.1175/2011JCLI4083.1, 2011.

Haywood, A. M., Dowsett, H. J., Otto-Bliesner, B., Chandler, M. A., Dolan, A. M., Hill, D. J., Lunt, D. J., Robinson, M. M., Rosenbloom, N., Salzmann, U., and Sohl, L. E.: Pliocene Model Intercomparison Project (PlioMIP): experimental design and boundary conditions (Experiment 1), Geosci. Model Dev., 3, 227-242, doi:10.5194/gmd-3-227-2010, 2010.

Haywood, A. M., Dowsett, H. J., Robinson, M. M., Stoll, D. K., Dolan, A. M., Lunt, D. J., Otto-Bliesner, B., and Chandler, M. A.: Pliocene Model Intercomparison Project (PlioMIP): experimental design and boundary conditions (Experiment 2), Geosci. Model Dev., 4, 571-577, doi:10.5194/gmd-4-571-2011, 2011.

Hill, D. J., Haywood, A. M., Hindmarsh, R. C. A., and Valdes, P. J.: Characterising ice sheets during the mid Pliocene: evidence from data and models, in: Deep time perspectives on climate change: Marrying the signal from computer models and biological prox ies, edited by: Williams, M., Haywood, A. M., Gregory, F. J., and Schmidt, D. N., the Micropalaeontological Society, Special Publications, the Geological Society, London, 517-538, 2007.

Holland, M. M., Bailey, D. A., Briegleb, B. P., Light, B., and Hunke, E.: Improved Sea Ice Shortwave Radiation Physics in CCSM4: The Impact of Melt Ponds and Aerosols on Arctic Sea Ice*, J. Climate, 25, 1413-1430, doi:10.1175/JCLI-D-11-00078.1, 2012.

Hunke, E. and Lipscomb, W. H.: CICE: The Los Alamos sea ice model, documentation and software, version 4.0, Los Alamos National Laboratory Tech. Rep. LA-CC-06-012, 76 pp., 2008.

Jahn, A., Bailey, D. A., Bitz, C. M., Holland, M. M., Hunke, E. C., Kay, J. E., Lipscomb, W. H., Maslanik, J. A., Pollak, D., Sterling, K., and Strove, J.: Late 20th Century Simulation of Arctic Sea Ice and Ocean Properties in the CCSM4, J. Climate, 25, 14311452, doi:10.1175/JCLI-D-11-00201.1, 2012.

Kay, J. E., Hillman, B. R., Klein, S. A., Zhang, Y., Medeiros, B., Pincus, R., Gettelman, A., Eaton, B., Boyle, J., Marchand, R., and Ackerman, T. P.: Exposing Global Cloud Biases in the Community Atmosphere Model (CAM) Using Satellite Observations and Their Corresponding Instrument Simulators, J. Climate, 25, 5190-5207, doi:10.1175/JCLI-D-11-00469.1, 2012a.

Kay, J. E., Holland, M. M., Bitz, C. M., Blanchard-Wrigglesworth, E., Gettelman, A., Conley, A., and Bailey, D.: The Influence of Local Feedbacks and Northward Heat Transport on the Equilibrium Arctic Climate Response to Increased Greenhouse Gas Forcing, J. Climate 25, 5433-5450, doi:10.1175/JCLI-D-1100622.1, 2012b.

Lamarque, J.-F., Bond, T. C., Eyring, V., Granier, C., Heil, A., Klimont, Z., Lee, D., Liousse, C., Mieville, A., Owen, B., Schultz, M. G., Shindell, D., Smith, S. J., Stehfest, E., Van Aardenne, J., Cooper, O. R., Kainuma, M., Mahowald, N., McConnell, J. R., Naik, V., Riahi, K., and van Vuuren, D. P.: Historical (1850-2000) gridded anthropogenic and biomass burning emissions of reactive gases and aerosols: methodology and application, Atmos. Chem. Phys., 10, 7017-7039, doi:10.5194/acp10-7017-2010, 2010.

Landrum, L., Holland, M. M., Schneider, D. P., and Hunke, E.: Antarctic Sea Ice Climatology, Variability, and Late Twentieth Century Change in CCSM4, J. Climate, 25, 4817-4838, doi:10.1175/JCLI-D-11-00289.1, 2012.

Lawrence, P. J. and Chase, T. N.: Representing a new MODIS consistent land surface in the Community Land Model (CLM3.0), J. Geophys. Res., 112, G01023, doi:10.1029/2006JG000168, 2007.

Lawrence, P. J. and Chase, T. N.: Investigating the climate impacts of global land cover change in the community climate system model, Int. J. Climatol., 30, 2066-2087, doi:10.1002/joc.2061, 2010. 
Lawrence, D. M., Oleson, K. W., Flanner, M. G., Fletcher, C. G., Lawrence, P. J., Levis, S., Swenson, S. C., and Bonan, G. B.: The CCSM4 Land Simulation, 1850-2005: Assessment of Surface Climate and New Capabilities, J. Climate, 25, 2240-2260, doi:10.1175/JCLI-D-11-00103.1, 2012.

Levitus, S. and Boyer, T. P.: World Ocean Atlas, Volume 4: Temperature NOAA Atlas NESDIS 4, U.S. Government Printing Office, 1994.

Lin, S. J.: A "vertically Lagrangian" finite-volume dynamical core for global models, Mon. Weather Rev., 132, 2293-2307, doi:10.1175/1520-0493(2004)132<2293:AVLFDC > 2.0.CO;2, 2004.

Loveland, T. R., Reed, B. C., Brown, J. F., Ohlen, D. O., Zhu, Z., Yang, L., and Merchant, J. W.: Development of a global land cover characteristics database and IGBP DISCover from $1 \mathrm{~km}$ AVHRR data, Int. J. Remote Sens., 21, 1303-1330, 2000.

Neale, R. B., Richter, J. H., and Jochum, M.: The impact of convection on ENSO: From a delayed oscillator to a series of events, J. Climate, 21, 5904-5924, doi:10.1175/2008JCLI2244.1, 2008.

Neale, R. B., Richter, J., Park, S., Lauritzen, P. H., Vavrus, S. J., Rasch, P. J., and Zhang, M.: The Mean Climate of the Community Atmosphere Model (CAM4) in Forced SST and Fully Coupled Experiments, J. Climate, online first, doi:10.1175/JCLI-D12-00236.1, 2013.

Oleson, K. W. and Bonan, G. B.: The effects of remotelysensed plant functional type and leaf area index on simulations of boreal forest surface fluxes by the NCAR land surface model, J. Hydrometeorol., 1, 431-446, doi:10.1175/15257541(2000)001<0431:TEORSP> 2.0.CO;2, 2000.

Pagani, M., Liu, Z., LaRiviere, J., and Ravelo, A. C.: High Earth-system climate sensitivity determined from Pliocene carbon dioxide concentrations, Nat. Geosci., 3, 27-30, doi:10.1038/ngeo724, 2010.
Richter, J. H. and Rasch, P. J.: Effects of convective momentum transport on the atmospheric circulation in the Community Atmosphere Model, version 3, J. Climate, 21, 1487-1499, doi:10.1175/2007JCLI1789.1, 2008.

Robinson, M. M., Dowsett, H. J., Dwyer, G. S., and Lawrence, K. T: Reevaluation of mid-Pliocene North Atlantic sea surface temperatures, Paleoceanography, 23, PA3213, doi:10.1029/2008PA001608, 2008.

Salzmann, U., Haywood, A. M., Lunt, D. J., Valdes, P. J., and Hill, D. J.: A new Global Biome Reconstruction and Data-Model Comparison for the middle Pliocene, Global Ecol. Biogeogr., 17, 432-447, 2008.

Salzmann, U., Haywood, A. M., and Lunt D. J.: The Past is a Guide to the Future? Comparing Middle Pliocene Vegetation With Predicted Biome Distributions for the 21st Century, Philos. T. R. Soc. A, 367, 16 pp. doi:10.1098/rsta.2008.0200, 2009.

Smith, R., Jones, P., Briegleb, B., Bryan, F., Danabasoglu, G., Dennis, J., Dukowicz, J., Eden, C., Fox-Kemper, B., Gent, P., Hecht, M., Jayne, S., Jochum, M., Large, W., Lindsay, K., Maltrud, M., Norton, N., Peacock, S., Vertenstein, M., and Yeager, S.: The Parallel Ocean Program (POP) reference manual, ocean component of the Community Climate System Model (CCSM), Los Alamos National Laboratory Tech. Rep. LAUR-10-01853, 141 pp., 2010.

Sohl, L. E., Chandler, M. A., Schmunk, R. B., Mankoff, K., Jonas, J. A., Foley, K. M., and Dowsett, H. J.: PRISM3/GISS topographic reconstruction, U.S. Geological Survey Data Series, 419, 6 pp., 2009 . 